\title{
How the Red Ring Became the Bronze Horse and the Horse Became the Ring: Tennyson’s “Boädicea”
}

\author{
Robert Keir Shepherd \\ Universidad Autónoma de Madrid, Madrid, Spain
}

\begin{abstract}
Tennyson's poem “Boädicea”, published in 1864 but at least conceived in 1858, has never been very highly regarded. It is usually omitted from editions of the complete poetical works. There are two reasons for this. Firstly, written in an approximation of Catullan/Callimachan galliambics, it is no easy read. Secondly and more importantly, however, it sits most awkwardly within a huge body of contemporary art -paintings, sculptures, and novels as well as poems which present the (properly) Queen Regent of the Iceni as the spiritual ancestor of Victoria (the Gaelic word boudicca does, after all, men “victory”). Far from portraying Boadicea (as the name was then commonly spelt from the 18th to themed 20th centuries) as the harbinger of British imperial glory, Tennyson presents her as the half-mad victim of Roman oppression, brutalized by her own experiences into a personal vendetta. I argue that this poem is a riposte to Sir William Thornycroft's bronze statue of Boadicea, a symbol of patriotic pride. It was begun at roughly the same time as the poem, both at the behest of Prince Albert; Tennyson would have seen Thornycroft's models. In the poem, Tennyson envisions Boädicea reducing Colchester and Londonto a red-black stain infested with carrion eaters, and he seems to be asking whether this colour, ironically reflected in the finished statue of the Regent, chariot and horses (she used cavalry and chariots to attack Londinium, after all) is anything like a becoming tribute to Victoria. As for the dating of composition, Tennyson's the most likely model for Boädicea is Lakshmibai, Queen Regent of Jhansi, who, during the Indian Mutiny of late 1857, is reputed to have ordered a massacre of English civilians who were tortured and dismembered in much the same as Boudicca's victims. The poem is thus a meditation on the evils inherent in empire building and its effect upon native peoples.
\end{abstract}

Keywords: become, empire, nation, tribe, massacre, madness

\section{Introduction}

Tennyson’s dramatic monologue "Boädicea” (supposedly written in 1859-1860 but see below) has never found favour with the reading public. That the choice of "pseudo galliambic" metrics make it so difficult to recite that only Tennyson could manage to do so convincingly is certainly part of the problem, but what I intend to show in this paper is that the reasons for its cool reception were, at least initially, rather more than simply aesthetic. When dealing with a work by the poet who dared to introduce criticism of British military blunders into the most patriotic of Crimean War poems ("The Charge of the Light Brigade", 1854), we should not, perhaps, be surprised to find a very well disguised critique of the activities of the British East India Company before and during the Indian Mutiny of 1857-1858 in a poem which deals fairly, if not quite squarely, with the degradation of a proud nation by an invader. For the British tribes under the Roman yoke read India, for

Robert Keir Shepherd, Ph.D., Professor, Department of English Philology, Universidad Autónoma de Madrid. 
Boädicea, Lakshmibai, the Rani (Queen Regent) of Jhansi state and one of the principal leaders of the rebel forces. For the invasive Roman Empire read its 19th century British equivalent. To both women Tennyson shows a certain sympathy balanced by sharp criticism of the brutality of their revolts. This did not go down well with the British public for two opposed reasons. First Victoria's Britannia as the world power was supposed to be beyond criticism of even the most veiled and qualified sort. Second, a cult linking Boadicea with strong British female monarchs had first become popular during the reign of Elizabeth 1 and was now all the rage once again. One of the most obvious symbols of this movement was a certain statue of the Queen of the Iceni which Prince Albert wanted to be erected in London. Boadicea, the warrior queen who had burnt Londinium to the ground, was to become the city's patroness in effigy. How Tennyson represented such an ambivalent clutch of associations in a poem which few people have ever read is to be the subject of this paper.

\section{A Mark of Respect Which Does Not Quite Ring True}

Boudicca $^{1}$ did not so much leave her mark on London as leave London as a mark on (now beneath) the ground. By the time she had finished with Londinium the military camp/supply base/port/town in the 60/61 A.D. rebellion it was reduced, in Peter Ackroyd's words, to a "fire-destruction horizon...to be found in a red layer of oxidized iron among a layer of burnt clay, wood and ash" (Ackroyd, 2001, p. 20). Comparing this layer to the first of the rings within the trunk of a tree which denote its age in human terms, we might say that this "firstborn" Londinium suffered cot death by fire. While we have created a mixed metaphor, then, the line of analogy is not quite so fanciful as it seems given that, as Tacitus, Cassius Dio and the inevitable charred bone fragments tell us, the Queen (properly, Regent) of the Iceni slaughtered babies and children as well as everyone else, everyone-Britons for the most part-whom the provincial governor Suetonius Paulinus had been forced to leave behind perished. They became the collateral damage which facilitated his retreat along Watling Street; deserting them gave him enough time to gather up the remnants of his forces from around devastated Colchester and St. Albans and then to regroup with the main body of his men who had been engaged in the campaign against the Druids on Anglesey.

Despite all this, Prince Albert managed to persuade Queen Victoria to allow him to encourage, if not actually commission, the stone version of the statue of charioted Boadicea flanked by her crouching daughters. It was created by Sir Thomas Thornycroft between 1856 and 1871—Boadicea's face is based on early portraits of Victoria herself-and in 1903 recast in bronze and erected on the Embankment where the Iceni queen's last confrontation with Suetonius' army was then thought to have taken place. The discovery of the copper-tinged destruction horizon served to compound the irony of which even Victoria—Boudicca's namesake—had been aware: that the self-appointed Mother of the British Empire was apparently condoning infanticide. The geographer Peter Taylor put the matter in a nutshell when he wrote that "on her route to historical glory, Boudicca razed London to the ground and slaughtered its residents. London is honouring its destroyer!" (Lawson, 2013). As such academics as Vanessa Collingridge attested, the association between Boudicca and the British monarchy begins, as it would, during the reign of Elizabeth I, goes into steady decline through a succession of kings but re-emerges in the late eighteenth century with the consolidation of the British Empire (Collingridge, 2006, pp. 296-391). When Victoria came to the throne in 1837 and still more when she was

\footnotetext{
${ }^{1}$ The conventional spelling for the name of the historical figure is now BOUDICCA. In the 18th and 19th centuries, it was generally BOADICEA. Tennyson has BOÄDICEA (with the umlaut). My spelling of the name will depend upon which of these I am referring to at any given point.
} 
proclaimed Empress of India in 1876, poets and every conceivable type of writer, politician, public speaker, and artist took their cue from William Cowper's “Boadicea, an Ode” (1782) and fused Boudicca and Britannia into a benevolent maternal figure who had suffered and been martyred in the attempt to retain national identity and now personified a humane, idyllic imperialism. Naturally, even in Elizabethan times, Boudicca had had her gainsayers, for every Raphael Holinshed a John Fletcher, and the same held true in the 19th century. Will it not surprise many readers to learn that foremost amongst those who questioned the assumption that Victoria was a Boudicca—Britannia hybrid was no less a figure than Alfred Lord Tennyson?

\section{What Kind of Monument Becomes a Queen?}

In this paper, I intend to examine a poem which, for reasons which will soon become apparent, I regard as a riposte both to Cowper's idealization of Empire and to Thornycroft's belief, grained into stone and beaten out in bronze, that an act of retaliatory aggression against a brutal imperialist cannot be deemed anything other than glorious. In Tennyson’s dramatic monologue “Boädicea” the Iceni Regent who envisions and encourages the torture and dismembering of non-combatants is as brutalized as the Roman invaders who stole her land, killed or enslaved her neighbours, raped her daughters and, this is what Tennyson makes her emphasize most, stripped and scourged her own body. The piece was at least conceived, I would argue, in 1858 or perhaps a little before-at least a year earlier than is generally cited. This is because it is very much a public poem, though not in the sense commonly believed. As very late it was written just after the Indian Mutiny of April 1857 to July 1858, for reasons which will be held back until the end of this paper in the interests, frankly, of suspense. In my title the verb "become" is used in two senses. The first, most obviously is "to undergo transformation into", referring to Boudicca's metamorphosis from the pyromaniac who razed Londinium to the ground into the national heroine who anticipated London's greatness. The second, however, is "to befit or be suitable to" as we attempt to explain how Tennyson implied that a bronze effigy was no apt memorial to adorn a patch of fossilized blood, melted copper, and charred bone. This is as savage poem which, both tonally and metrically, owes a great deal to an equally savage hypotext-Catullus Ode 63, which describes the crazed self-emasculation of Attis and the temporary insanity he is powerful enough to induce in his companions so that they follow suit. The mere of "Boädicea" is no galliambic; it more resembles Longfellow's Hiawatha (trochaic tetrameter) "with the occasional dactyl worked into the sixth foot" (Ferguson, 1969, p. 42), but it serves its purpose of unsettling the reader as well as either Catullus or Callimachus. The question raised, then, is of whether Boädicea, by assuming the role of warrior prophetess and infanticide, has not become a Lady Macbeth who could commit murder as well as inspiring someone else to do so.

It seems logical to assume that Prince Albert requested both sculptor and poet laureate to create their works on Boudicca at more or less the same time. We know nothing about the nature of their collaboration or, indeed, if they ever consulted at all. Suffice to say that it looks very much as if Tennyson had seen at least a model or drawings of Thornycroft's work, since his opening description (i.e., before the Queen actually begins her monologue) seems to be based on the statue, though in a manner subtle enough to suggest misrepresentation that is both parodic and psychologically acute. Here are the lines, followed by a photograph of the statue, and it is well worth noting that on the plinth, hidden in the photograph, is an inscription formed by an elision of two lines from Cowper’s “Boadicea, an Ode”, to wit "Regions Caesar never knew thy posterity shall sway”. Such a statement might be deemed rather unfortunate since "sway" when used poetically might mean "to rule or hold sway over" as much as "to persuade", while the reference to Caesar implies comparison as much as contrast. A 
British monarch might well create an empire greater than that of Rome, but will the means of conquest be any different to those of Nero, the Emperor who ensured that procurator Catus Decianus would confiscate Boudicca's land and have her flogged? We shall be looking at Tennyson's reworking of these lines below, but as for his opening gambit;

\footnotetext{
While about the shore of Mona those Neronian legionaries Burnt and broke the grove and altar of the Druid and Druidess, Far in the East Boadicea, standing loftily charioted, Mad and maddening all that heard her in her fierce volubility, Girt by half the tribes of Britain, near the colony Camulodune, Yell'd and shriek'd between her daughters o'er a wild confederacy (1-6) ${ }^{2}$
}

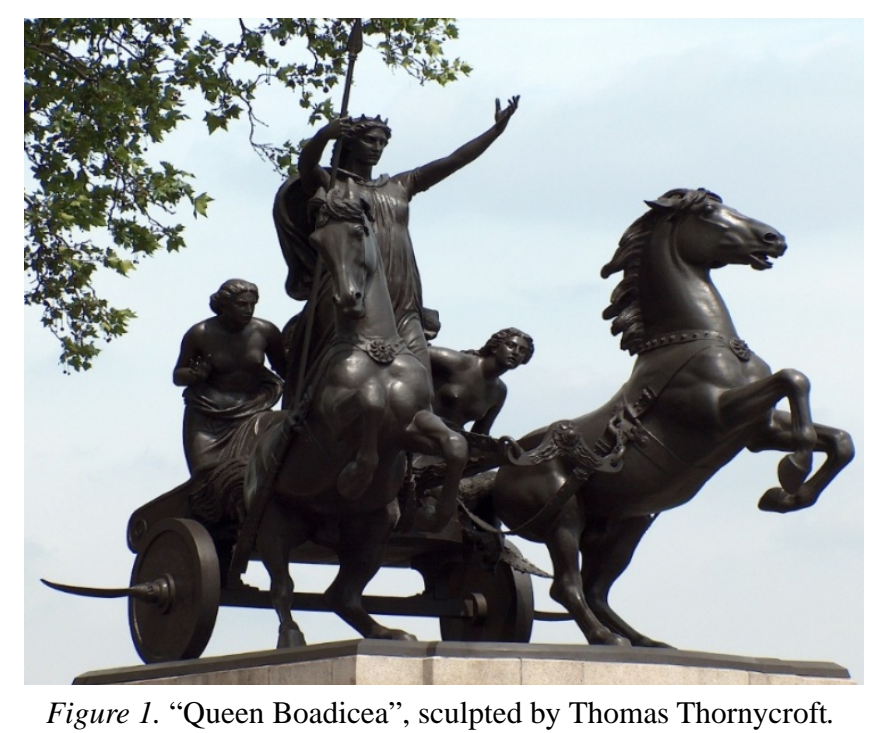

As far as the statue is concerned (see Figure 1), Boadicea certainly does "standing loftily". So anxious is Thornycroft to suggest strength and (perhaps divinely aided) regality of poise, that he completely ignores rearing horses, reins to control them and the law of gravity. That sloping spear seems to be all that holds Boadicea upright. Look back at Tennyson, however, and you will see that his use of "loftily" is Miltonic in its double-voicedness. It seems rather to imply "at a height above” than anything else since, although the chariot gives her a vantage point over her followers, her behaviour is anything but queenlike "Mad and maddening all that heard her in her fierce volubility... Yell'd and shriek'd between her daughters o'er a wild confederacy." No; whether by design or simply because she cannot help herself she has turned utterly hysterical, and that hysteria is contagious. One could say either that she is whipping up her motley army or dragging them down to her own level of animal savagery. In Catullus 63, Attis (“unsexed”, remember) is in a comparable and equally contagious state of mind;

simul haec comitibus Attis cecinit notha mulier thiasus repente linguis trepidantibus ululate. ${ }^{3}$ ( Merrill, 2015, Catullus 63)

\footnotetext{
${ }^{2}$ Hodder, K. (Ed.) (2008), all citations from the poem are taken from this edition.

3 The translation is made by the author.
} 
As soon as Attis, a woman who was not a real woman, chanted in this way to her followers, the celebrants suddenly with quivering tongues yell out loud.

As for the daughters, their present all-consuming purpose seems to be that of propping up their mama, or at least attempting to make sure that she doesn't topple beneath the chariot wheels and their entirely a-historical scimitar attachments. Do their crouch and bare-breastedness indicate the intention of risking life and limb (particularly scythed ankle bones) as they leap off berserker-like into the fray (though they are both unarmed), a catatonic inability to dress after being raped or...something else? I would suggest that it is this "something else" which Tennyson brings into his word picture, and my own flippancy here is also intended to indicate that the poet had not only seen a version of this statue and thought it more than slightly daft, but had also decided to incorporate that sense of the ridiculous into a work in which any humour was decidedly black.

Tennyson's Boädicea may well be tottering on the brink of insanity, but there is a method in her madness, a certain poise over the brink. As stated, there is certainly little of the regal in her attitude; rather, she clings to a form of low cunning. Those daughters, why are they there on either side of her? Here again, the poet seems to be taking advantage of the sculptor's lack of psychological insight. His Boadicea is supposed to be a wholly emblematic figure - the mother of British national pride. Cowper had done rather more than "lean towards" this interpretation of her attitude (physical as well as mental) back in 1782. Most of the Ode is taken up with the chief druid's prophecy of Britain's eventual greatness. The fall of the Roman Empire and the rise of its infinitely greater British counterpart form the final link in a chain of causation initiated by Boadicea: it is as if she were great with the child of her nation's future. Images of metaphorical childbearing are foregrounded in the final stanzas of the poem; "The progeny that springs / From the forests of our land...Shall a wider world command" (Cowper, n.d.); "Such the bard's prophetic words / Pregnant with prophetic fire ...She, with all a monarch's pride / Felt them in her bosom grow". Transform "monarch" into "mother", read "womb" for "bosom" and you are catching Cowper's meaning. A monarch who is the mother of her race; perhaps it was this expression of the idea that encouraged Victoria to put up with the Boadicea cult in the first place.

Yet is it not the role of a mother to protect her offspring? Look at any other comparable representation of Boadicea and her ravished daughters and in nine cases out of ten you will find them enveloped in her cloak or huddled between her legs. ${ }^{5}$ Such was not the case with the Thornycroft statue, however, and Tennyson, in this case making sound psychological sense of the postures of the sculpted figures, hints at the reason. In point of fact, we have already hinted at it ourselves by joking that the daughters prop their mother up, for props are exactly what they are in Tennyson's dramatization of the statue-stage props. Their principal function is surely to whip up the tribal mob even more, and far from wishing to cover their nakedness, their mother uses it as a piece of anti-Roman propaganda. In her present state of mind, could she actually care less about her children?

\section{The Politics of Prophecy and a Black Ring}

It is most certainly true that, in Tennyson's version of the events, Boädicea's furious desperation and the need for her to assume the role of maddened and, as we are about to see, priest-like avenger would normally be all too understandable. Unlike Cowper, he has gone to some pains to outline the historical events as accurately as Tacitus and Cassius Dio will allow him. This is evident as soon as the poem begins; Boädicea is gathering

\footnotetext{
${ }^{4}$ See from http://www.bartleby.com/41/320.html. All references to the poem are taken from this webpage.

${ }^{5}$ For example, "a very maternal picture of Boudica with her daughters" (Collingridge, 2005) painted in 1916 by James Harvard Thomas. A photograph of the work appears on page 381 of the book.
} 
her forces "While about the shore of Mona those Neronian legionaries / Burnt and broke the grove and altar of the Druid and Druidess". ${ }^{6}$ So much was true. The attack on Mona was one of the principle reasons for the timing of the Iceni revolt because Suetonius Paulinus had taken the bulk of his troops into Wales to cross over to Anglesey and crush the Druids, rightly judged to represent the backbone of tribal resistance. London, Colchester and St. Albans had been left with only skeleton garrisons, so what better time to rebel? The Anglesey massacre - no quarter given to anyone did create one major problem for Boudicca, however and Tennyson picks up on it;

Stabat pro litore diversa acies, densa armis virisque, intercursantibus feminis, [quae] in modum Furiarum veste ferali, crinibus disiectis faces praeferebant; ... dein cohortationibus ducis et se ipsi stimulantes, ne muliebre et fanaticum agmen pavescerent, inferunt signa sternuntque obvios et igni suo involvunt. ${ }^{7}$ (Tacitus, n.d.)

The enemy army stood on the shore with its dense array of armed warriors, while between the ranks there ran women, dressed in black like the Furies, with hair dishevelled, waving torches. Then goaded on by their commander's appeals and egging each other on not to flinch before a troop of madwomen, they carried the standards forwards, beat down all resistance, and wrapped the foes in the flames that they themselves had lit.

Boädicea is well aware that, unlike her Cowperian counterpart, she can appeal to no higher spiritual power to calm and reassure her of the validity of her efforts. In the Ode we find:

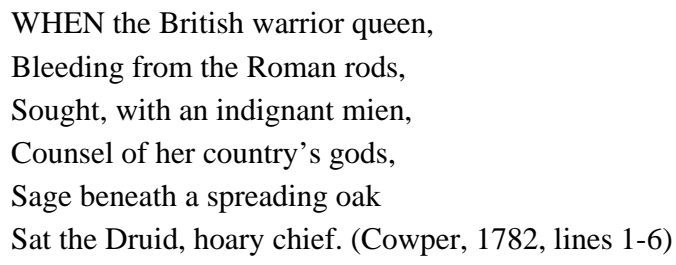

There is no such pillar of strength and comfort for Boädicea. Even the druidesses have been slaughtered, thus emphasizing the fact that, to make up for her lack of a higher spiritual authority, she must play the role of prophetess herself. And it must be said that she is hardly the adequate person for the job. Cowper's druid speaks with the foresight of late Georgian hindsight; the first volumes of Gibbon's The History of the Decline and Fall of the Roman Empire had appeared in 1776, remember, six years before this poem's publication, even if the poet does not seem to know his Gaul from his Goth;

Rome, for empire far renown'd,

Tramples on a thousand states;

Soon her pride shall kiss the ground-

Hark! the Gaul is at her gates! (Cowper, 1782, lines 17-20)

Now in the fourth verse paragraph of the poem (lines 34-46), Boadicea does say that she has already heard the voices of druidesses forecasting a noble future for Britain. It is far from clear, however, whether she has stumbled across and overheard the voices of those taking part in some form of ritual, was simply delirious and maddened at the time and hearing things (did the experience occur, perhaps, after her beating?), or is making the whole experience up:

\footnotetext{
${ }^{6}$ The emphasis is made by the author.

7 The translation is made by the author.
} 


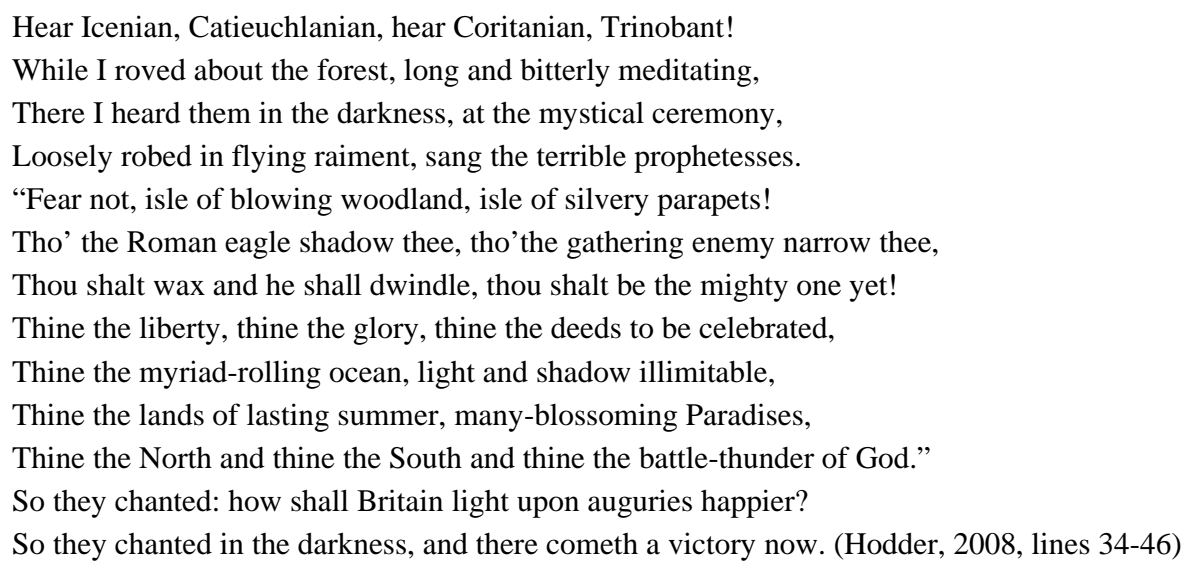

Tennyson is not one to forget minor yet crucial details in a dramatic monologue when little slips and contradictions reveal rather larger untruths. Did she only hear voices or witness a ritual? How could she see it in the dark? In what sense are prophetesses "terrible” when they speak of pastoral idylls and the late Iron Age version of "Rule Britannia"? She cannot stay away from her pet topics-her torment and lust for vengeance-for very long, so surely the best reason for believing that this sunny interlude is invented is that it ends so incongruously with a "thine the battle-thunder of God" (actually echoing Cowper's rather unfortunate “armed with thunder, clad with wings” when describing a supposedly benevolent Britain), before returning to thoughts of the coming massacre in which, of course, she cannot but be victorious, however, temporarily. Anyone blessed with common sense would see these lines as a cunning parody of Cowper, whose Boadicea knows full well that she will be defeated and killed ("Rushed to battle, fought, and died") and is heartened by the druid's promise of a peaceful British Empire (“Sounds, not arms, shall win the prize”). Regent Boädicea, however, seems unwilling or unable to see any further than the next warm and invigorating bloodbath.

The woman is no druidess, then, but existence on the lunatic fringe of desperation turns her in all but the pastoral lapse into an effective rabble-rousing orator, though one whose words hardly stand up to close critical scrutiny. She faces a daunting task: that of finding a way to transform a personal vendetta into a "national" cause when there is no real nation she might make an appeal to. Not to qualify such a claim as this would be downright un-Tennysonian, so one must add that her attacks on at least two of the three settlements are, by implication, justified within the poem in that the places were anathema to at least the majority of Britons, and shared hatred of a common enemy binds factions, however, loosely. "Lo the colony, there they rioted in the city of Cunobeline!” (line 60). Camulodunum, which, irony of ironies, had actually been forcibly occupied by Cunobelinus the king of the Catuvellauni and wrested from the Trinovantes around 9 A.D., surrendered to Claudius' army in 43 and was turned into a colony for Roman veterans in 49. The native inhabitants were forcibly ejected, and many enslaved. "Then a phantom colony smoulder'd on the refluent estuary" (line 48) should refer to Londinium where the Romans took full advantage of the flow and ebb tides of the Thames Estuary to ship in military supplies and start off a lucrative export business in British slaves; it is certain that a fair proportion of the native inhabitants of Camulodunum and many other native settlements passed that way. This being the case, the sheer ease of ingress and egress and the presence of a population of foreign merchants and sailors made it a prime object of tribal hatred.

Such "hate objects" were very necessary to Boädicea, however, a fact which Tennyson makes clear (though, as ever, hardly abundantly clear) by repeating the same four words (or combinations of them) no less 
than five times in the poem; “Hear Icenian, Catieuchlanian, hear Coritanian, Trinobant!” (lines 10, 21-22, 34, 47, 58). This is a particularly difficult mouthful of tribal names to pronounce, so whenever they appear they stick out like a sore tongue. They are meant to, since the problem with them goes far beyond mere pronunciation, as is pointed out as early as line 5 and emphasized in 8; "Yell'd and shriek'd between her daughterso'er a wild confederacy" and "They that scorn the tribes and call us Britain'sbarbarous populaces". The truth of the matter, and how well Boädicea knows it, is that the Romans are perfectly right to classify the "Britanni" not as a nation but an unruly collection of peoples who generally fight amongst themselves when not (and actually often whilst) fighting the invader. She only refers to them directly as a united people/country three times (“noble heart of Britain”, "Britain’s raven”, “Up, my Britons” lines 12-13, 69) to herself as a "Britoness” once, (line 55) and as a country, Britain, once, as we have just seen. That makes the references to separate tribes and to a united country more or less equal; Boädicea is obviously undecided on how to address "her" "people(s)" at best, and when allusions to a single country do appear, none are any less forced than, say, "Friends, Romans, Countrymen" or "Once more into the breach, dear friends, once more /Or close the wall up with our English dead!” As with Mark Antony or Henry V, there is a kind of cold reasoning behind her fervour of skewed patriotism, but in most cases her clumsy handling of the terminology of national unity is all too obvious. How could it be otherwise? She knows little or nothing about it.

The word "confederacy" has two principal meanings, of course: "A union or league or contract between persons, bodies of men or states, for mutual support or joint action; a league, alliance, compact” or “ A league for an unlawful or evil purpose; a conspiracy” (Murray, Bradley, Craigie, \& Onions, 1978, Vol. II, p. 797). Both the Regent-Queen of the Iceni and the tribal gathering are conscious of taking joint action for a just cause, yet they still act and sound like a mob ganging up against the helpless while their protectors are absent. Moreover, it is all too obvious that their leader never hesitates when referring to the enemy as a united people; "Such is Rome", "Roman carrion”, "Roman robbers", “Roman liars”; the nouns are always pejorative, naturally, but there is never any doubting the fact that Rome and its allies are able to carry out atrocities because unity equals strength.

The most glaring indication in the monologue itself that there is a serious flaw in Boädicea's turn of phrase and state of mind comes when she touches upon nationalistic symbolism;

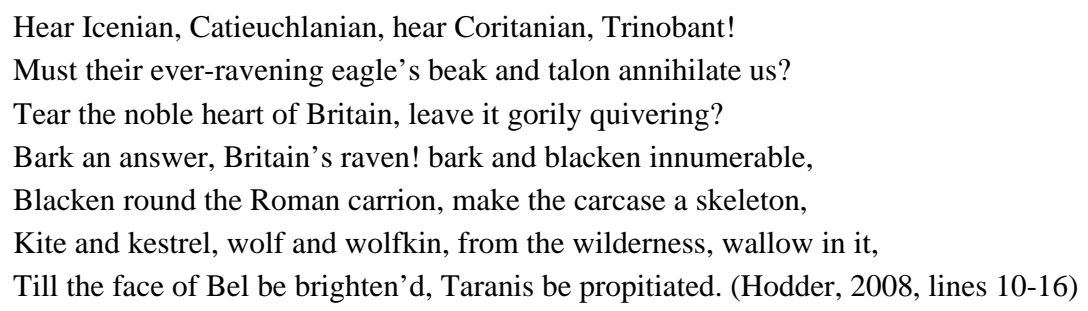

Fumbling for a British ("Britanni” is a gallo-roman coinage, remember) counterpart for the Roman Eagle, symbol of armed might and imperial power, she happens upon the raven. This is not entirely an accidental stumble. The raven was the sacred bird of the Celtic deity Brân, whose severed head (the head was deemed the repository of the soul, and quite rightly too) was said to be buried beneath the site of the Tower of London. Like Cowper's venerable chief Druid, then, Boädicea references future events-in this case the association of the London ravens and national security which even Winston Churchill respected—but is obviously unaware of what she is doing. What would the Tower of London be to her beyond a temporary look-out post which must be 
sent toppling? Unlike the Druid's, her thoughts are not so much of long term greatness as of short term victory. The raven, always present on battlefields to feast on the despoilment of war, was associated in Celtic mythology with the goddesses of armed conflict, slaughter and death-Morrígan, Macha and Nemain. Very probably Boädicea is striving to assume all three aspects of what is actually a tripartite deity, respectively "the Great Queen”, “the Crow” (Macha in her manifestation of Badb) and "Battle Frenzy”. ${ }^{8}$ The mental preparation for the role of murderous berserker monarch only accounts in part for her fumbling discourse, however. Remember that this was a woman who, with her husband Prasutagus, had lived most of her life as a client monarch under Roman authority. Being a product of two cultures she inadvertently opposes one national bird-emblem with another, and the result is incongruous-dangerously so. What is essentially a carrion crow cannot hope to win a battle against the greatest hunter-killer of the avian world, and her imagination stops short at the challenge of envisioning a straight contest between the two. Instead, she summons reinforcements to the "British Raven's" aid; one of the noises made by the bird is indeed called a bark but that bark soon becomes the snarl of a wolf, a pack predator, which is joined by its young and other carrion birds that crowd round corpses. Here, then, is our original "mark" again, the most horrific tableau in poem which is already brimful of awful scenes, the copper stain now a squawking, snarling, biting, clawing scarlet/black mass. Is this "the noble heart of Britain"? If a motley crew of barely unified tribes created it, the raven-led pack of beasts cleaned up the remains; surely Tennyson was very well aware that the collective term for ravens is "a conspiracy". And a conspiracy against what? If the enemy is an (E)agle it is an old, fledgling or wounded one, too weak to fight back, and it is only a short step from the image of the weak as prey to a description of the fall of the defenceless Roman colonies;

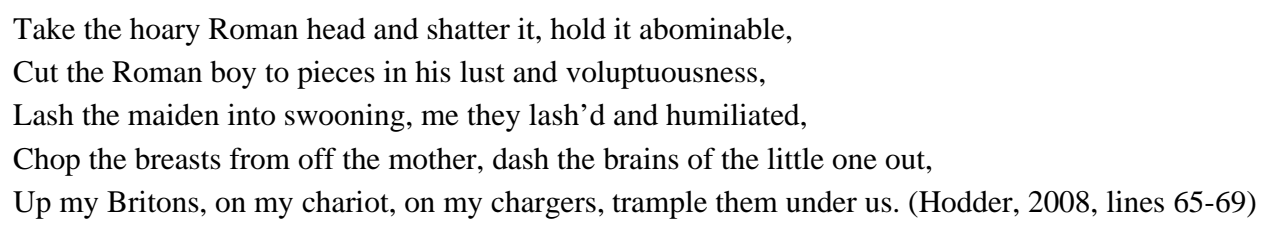

This is not war she envisions, but revenge as coldblooded murder. Certainly it is a reprisal, an eye for an eye, a tooth for a tooth; certainly it is justified by the Old Testament prophets and even referred to in those last two lines of Psalm 137 ("By the rivers of Babylon”) which no-one ever sings;

O daughter of Babylon, who art to be destroyed; happy shall he be who rewardeth thee as thou hast served us. Happy shall he be, that taketh and dasheth thy little ones against the stones. (KJV, 1994, p. 521)

Yet Boädicea, in effect, has demonized and "unsexed" herself to the extent that she will indeed become what Lady Macbeth only boasted that she could be and instead turned her husband into a killer of babies and children as well as the aged. If character is only proven and attested by actions, then "the noble heart of Britain" (the nearest pre-Roman approximation to which now lies under a scattering of ash on Mona where the Romans "(b)urnt and broke the grove and altar of the Druid and Druidess") will shortly exist in a stinking black pool of extinguished life or a red ring of melted copper. When it comes down to it, one has to say that the very little Boädicea knows about empire building she has learnt from the Romans. She knows how to call foreigners scum

\footnotetext{
${ }^{8}$ The Celtic mythological materialis taken from my own notes taken during postgraduate tutorials at Trinity College, Dublin, but also see Ó hÓgáin (1991), pp. 307-309. When the ravens in the Tower of London died off during World War II, Churchill ordered replacements to be found with startling celerity.
} 
and treat them as such, quite literally ("Roman carrion”). She knows how to take advantage of the defenceless, especially of women (“Lash the maiden into swooning, me they lash'd and humiliated”). She knows how to turn state religion (basically the worshipping of idols) into a powerful weapon: the Romans turn a man into a god (There the horde of Roman robbers mock at a barbarous adversary/ There the hive of Roman liars worship a gluttonous emperor-idiot), whilst she, in the absence of any higher religious authority, adding self-made priest to the role of self-made man, can see God in any natural phenomenon that happens to occur;

Hear it, Gods! the Gods have heard it, O Icenian, O Coritanian!

Doubt not ye the Gods have answer'd, Catieuchlanian, Trinobant.

These have told us all their anger in miraculous utterances,

Thunder, a flying fire in heaven, a murmur heard aerially. (Hodder, 2008, lines 21-24)

Very probably, in the absence of such occurrences, she even makes a shrewd guess as to what a Roman trading centre will look like when she has finished with it. Note that in this case the vision of dead soldiers and cavalry floating in the Thames is purer fancy than normal; she would hardly have known that Suetonius Paulinus would strip Londinium even of its skeleton defence, especially the cavalry;

Phantom sound of blows descending, moan of an enemy massacred,

Phantom wail of women and children, multitudinous agonies.

Bloodily flow'd the Tamesa rolling phantom bodies of horses and men. (Hodder, 2008, lines 26-27)

In the light of such a forthright set of lines as this, it is really quite difficult to see why such commentators as Marguerite Johnson are so anxious to force "Boädicea" the poem into the Victorian jigsaw picture of benevolent British imperialism and even why Richard Hingley (2000) and Deirdre David (1995) stumble over each other in the attempt to classify the Icenian Queen's rage as little more than "an instructive contrast to the venerated moral serenity and middle-class propriety of Victotia" which is couched in "a rollicking exercise (!) in galliambic verse” (David, 1995, p. 174). One only hopes that Tennyson's poem helped to turn Victoria against the Boadicea cult or good, and that perhaps events in India in the summer of 1857 and the British public's reaction to it influenced the monarchs interpretation of her poet laureate's work when it finally appeared in print.

\section{Two Queen Regents and the Empress of India}

When citing "Boädicea", one notes that all three of the commentators mentioned above give the date of publication (1864) and not even the one generally accepted for composition composition (late 1859/early 1860, and see above page 2) thus distancing the work from the catastrophe which inspired it, namely the Indian or Sepoy Mutiny which began in earnest on the 10th of May 1857 when the Native Indian soldiers under the effective control of the East India Company in what is present day Uttar Pradesh, Bihar, northern Madhya Pradesh, and the Delhi region rose up against, first, the army, then the non-Indian population of these areas. The reasons for the rebellion are certainly comparable, if far from identical, with that of the Iceni; land confiscation, at least perceived intent to make Buddhists and Muslims break the rules of their religious faith and lose not merely divine grace but the rights accorded to cast in so doing. Comparing Nero's failure to honour land treaties made with the British tribes during the reign of Claudius, the erection of the statue to the deified late Emperor in Camolodunum and the immolation of Mona. Comparisons even extend to the presence of a bloodthirsty Indian Boädicea in the figure of Lakshmibai, the Rani (Queen regent) of Jhansi state, one of the 
principal leaders of the rebellion who earlier had lost her kingdom as a result of the Doctrine of Lapse, according to which land belonging to a feudal ruler became the property of the East India Company if on his/her death, the ruler did not leave a male heir through natural process. It had long been the custom for a childless landowner to adopt an heir, but in the case of Lakshmibai's son by adoption the East India Company ignored this tradition. It is surmised, though it has now been almost certainly disproven, that Lakshmibai as head of the effectively deposed royal house took vengeance on the British by ordering the torture, rape dismembering and disposal down a sixty-foot well of 61 English asylum seekers (mostly women and children) at Jhansi on July 15th 1857. The accounts of Lakshmibai's resistance to the East India Company and its troops have so much in common with Boädicea's resistance to the Romans that it is very difficult to understand why commentators on the Tennyson poem have completely ignored the similarities up to now. I would personally go so far as to say that, whether he believed the rumours about the massacre or not, Tennyson's Celtic Regent as acting-Monarch is most certainly the Rani of Jhansi mounted on a chariot as opposed to a charger; rather maddening her troops with an harangue than calming her dependents with a, granted, politically charged speech given at a gift-giving (Haldikumkum) ceremony; surviving a series of Roman rather than British-led attacks during which no quarter was ever given by either side and hideous reprisals on civilian populations were common to both; dying on or near the battlefield yet leaving behind ambiguous tales as to the actual nature of her death and location of place of burial. ${ }^{9}$ Above all, one feels, Tennyson would have been motivated to write his poem not about a Victoria, in-effigy or anything like one (or even so unlike one as to have amounted to an anti-Victoria). No; in creating a poem which, as a dramatic monologue quite naturally focuses upon the psyche of the bloody minded speaker yet, precisely because it does so, makes no bones whatsoever about the inhumanity of the "Imperial” enemy, Tennyson would most probably have been inspired by his Queen's public expressions of horror leavened with a compassion for and even understanding of the Indian mutineers and fury that soldiers representing the British Empire should so lower themselves as to participate in the same kind of atrocity;

\footnotetext{
“There is a rabid and indiscriminate vindictiveness abroad, even among men who ought to set a better example, which it is impossible to contemplate without a feeling of shame for one's own countrymen,” Lord Canning wrote to the Queen...The Queen was entirely in agreement with the Governor-General. She considered the shouts for bloody revenge "too horrible and really quite shameful". There must, of course, be suitable punishment for the perpetrators of these "awful horrors”, but... "They should know that there is no hatred to a brown skin-none..” ...” think the greatest care ought to be taken not to interfere with their religion... as once a cry of that kind is raised among a fanatical people there is no knowing what it may lead to and where it may end” (She ensured that Canning swore a solemn oath to Lord Granville, Lord President of the Queen's Council that) ...I will never allow an indiscriminate act or word to proceed from the Government of India as long as I am responsible for it. ${ }^{10}$ (Hibbert, 2000, p. 250)
}

It must be said that it is not precisely this type of compassion for Boädicea and her people(s) that Tennyson's poem inspires, whatever his intentions when writing it. If judged as a public poem pure and simple, as an expression of disgust at British government in India and its effect of bringing out the very worst in the native population, then one would have to say that the line "Out of evil evil flourishes, out of tyranny tyranny buds” (Hodder, 2008, line 83) is a case of too little said too late. How many readers actually realized that the poem was a meditation on the Lakshmibai incident? Few commentators I have read even mention India: Vanessa Collingridge does refer to the Indian Mutiny but places far more emphasis on the poem's connections

\footnotetext{
9 This material is gathered mostly from Meyer and Blair (1999). See References

10 The Interpolation is made by the author.
} 
with the Crimean War (Collingridge, 2006, pp. 356-358, 380, 388).

The problem, if the failure to make the parallelisms more obvious in "Boädicea" is a problem, was Tennyson's decision to bring the dramatic monologue into the sphere of occasional verse. He opted for a poetical genre which, more than any other, reveals the darker, less empathic side of the narrator's mind. Here is a woman who has seen her own and other tribes massacred and enslaved; as if that were not enough, her own daughters have been gang-raped. Is this of all-consuming importance to her, though? Look at the amount of times the first person pronoun is employed in the following passage and judge for yourselves;

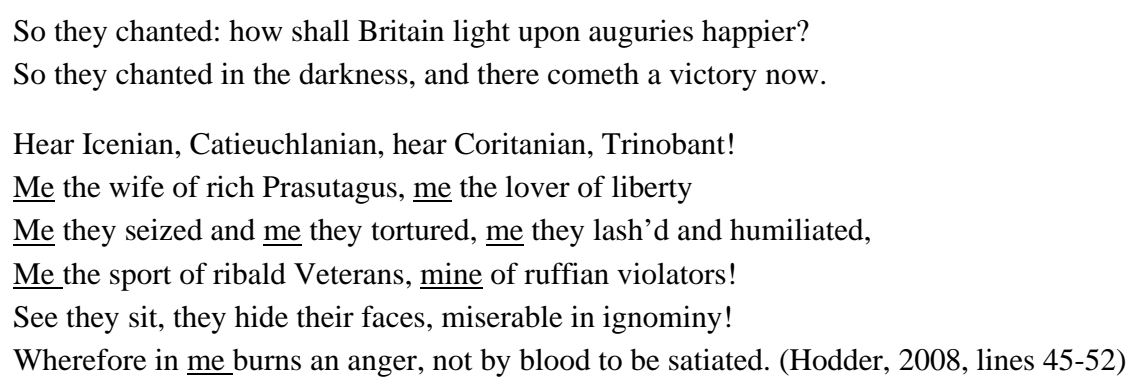

That is seven "me's” in eight lines, and two violated, half-naked daughters referred to almost as personal possessions ("mine") while Britain is referred to once. Resorting to semantic fields as a tool for analysis is generally a fairly lazy way to approach a text, but here it speaks for itself. Boädicea and her personal affront are far and away the most important measure of the vengeance she will take against the Romans and everyone else who happens to be in the vicinity. The references to what might lie beyond that vengeance- the island's future-comes across as forced. The objection will be raised that her discourse extends to Roman land-grabbing, emperor worship, licentiousness and respect for the heroic British past;

Lo the colony, there they rioted in the city of Cunobeline!

There they drank in cups of emerald, there at tables of ebony lay,

Rolling on their purple couches in their tender effeminacy. (Hodder, 2008, lines 60-62)

There the horde of Roman robbers mock at a barbarous adversary.

There the hive of Roman liars worship a gluttonous emperor-idiot.

Such is Rome, and this her deity: hear it, Spirit of Cassivelaun! (lines 18-20)

Note, however that she mentions only one symbolic and emotional centre for all this hatred "There! ... There! ...”,

There they ruled, and thence they wasted all the flourishing territory,

Thither at their will they haled the yellow-ringleted Britoness- (lines 54-55)

"There" in all three cases is Camulodunum, so closely associated with Cunobelinos (Cymbeline) who, as noted, took over the town in 10 A.D. and was the king of the same tribe (the Catuvellauni) which produced Cassivelaunus, the most famous British opponent of Julius Caesar. And while the Britoness might refer to all the women from the tribes who were dragged there to be raped or held for transportation to Londonium, there is little doubt that it is he own shame and pain at the hands of the wielder of the whip at, precisely, Colchester that is uppermost in her mind. It is not even so much the Romans in general as the Romans dwelling in Colchester that are her overriding hate object, and she really does not seem to be able to see anything further into the future than the day on which she will ride over it (Up my Britons, on my chariot, on my chargers, trample them under 
us) her horse perhaps bronzed against the firelight, and leave it a pile of ash. One even begins to wonder whether or not, in line 27, she has not confused the river Thames with the Colne. In so many modern novels about the Boudica revolt we note that writers centre upon the destruction of Colchester rather than that of London simply because both Tacitus and Cassius Dio give us most information about it. Tennyson, however, has a good reason for leaving direct naming of the English capital right until the last line, and making it the only city referred to in the poem which retains its modern spelling;

Fell the colony, city, and citadel, London, Verulam, Camulodune. (Hodder, 2008, line 86)

London was Tennyson’s capital, Victoria’s, the British Empire’s. To Boädicea, however, Londinium was merely another future Roman blot on the landscape, or rather another raven-black patch were Rome had been blotted out again, a replica of her avenged disgrace at Camulodunum. How she would have laughed, Tennyson must have been thinking, if she had known that plans were afoot to situate the commemoration of her vengeance on Colchester in a city she had once wiped out as practically an afterthought. One wonders if Tennyson’s Boädicea was even interested enough in Londinium to remember its Latin name.

\section{Conclusion}

As far as I am aware Victoria's opinion of "Boädicea” as a poem has gone unrecorded. Doubtless they discussed it either during an audience at Buckingham Palace or even on the Isle of Wight, yet had she made a public pronouncement on either of the two burning questions it addresses one feels that it would have earned a much higher place in the Tennysonian canon; it certainly would not have been almost wholly eradicated from it. The first question is obviously that of the justification or non-justification of the "two eyes for an eye, the whole head for a tooth" nature of the vengeance of the oppressed, and here Tennyson's restraint and sensitivity is exemplary. Now "restraint" and "sensitivity" may well be strange words to use when referring to such a blood thirsty and noisy poem. One marvels, however, at the surefootedness with which the poet treads the dividing line between horror at Boädicea's viciousness and sympathy with the maddened victim of the chain of events that caused it. He demonstrates complete understanding of the "brutalized brutality" which is the byproduct of empire building. How ill-deserved his reputation as the overloud and thoughtless trumpeter of "Rule Britannia" really is! You do not turn Cowperian tub-thumping on the theme into a thoroughly engaging dramatic monologue unless you can see, like Victoria, that there is a multiplicity of sides to every question. What is the dramatic monologue actually for if not to reveal depths of opinion and pure (impure?) feeling so hidden that even the speaker is wholly or partially unaware of them? Robert Browning was not the only late 19th century master of the form.

The second question is that of the mythologization of monarchy. As already stated, Gibbon had effectively turned history into a science, Macaulay and a host of others were following suit. There was therefore no excuse for not questioning the aptness of the Vice-Regent of the Iceni as a national figurehead. And once again Tennyson seems to have been completely in tune with his monarch's opinions on the subject. Not for nothing was the public unveiling, the Embankment debut, of Thornycroft's statue held back until two years after Victoria's death.

\section{References}

Ackroyd, P. (2001). London: The biography. London: Vintage. Collingridge, V. (2006). Boudica. London: Random House. 


\section{HOW THE RED RING BECAME THE BRONZE HORSE AND THE HORSE BECAME THE RING}

Cowper, W. (n.d.). Boadicea, an ode. Retrieved from http://www.bartleby.com/41/320.html David, D. (1995). Women, empire and Victorian writing. New York: Cornell University Press.

Ferguson, J. (1969). Catullus and Tennyson. English Studies in Africa, 12(1), 41-58.

Fisher, C. D. (Ed.). (1906). Conelii Taciti Annalium. Oxford: The Latin Library. Retrieved from http//www.thelatinlibrary.com/ Hibbert, C. (2000). Queen Victoria: A personal history. London: Harper Collins.

Hingley, R. (2000). Roman officers and English gentlemen: The imperial origins of Roman archaeology. London: Routledge. Hodder, K. (Ed.). (2008). The works of Alfred Lord Tennyson. London: Wordsworth Poetry Library.

Johnson, M. (2012). Boudicca. Bristol: Bristol Classical Press.

KJV (King James Version) Refence Bible. (Noeditor cited). (1994). Michigan: The Zondervan Corporation.

Lawson, S. (2013). Nationalism and biographical transformation: The case of Boudicca. Humanities Review, 19(1), 101-119.

Merrill, E. T. (Ed.). (2015). Catullus Carmina. N.Y.: Tufts Digital Library. Retrieved from http://www.perseus.tufts.edu/hopper/ Meyer, K. E., \& Brysac, S. B. (1999). Tournament of shadows. Washington, DC: Counterpoint.

Murray, J. A. H., Bradley, H., Craigie, W. A., \& Onions, C. T. (1978). The Oxford English dictionary. Oxford: Oxford University Press.

Morton, H. V. (2002). In search of London (p. 65). N.Y.: Da Capo Press.

Ó hÓgain, D. (1991). Myth, legend and romance: An encyclopedia of the Irish folk tradition. Oxford: Prentice Hall Press.

Tacitus, P. C. (n.d.). Annalium Liber Qvartvs Decimvs. Retrieved from http://www.thelatinlibrary.com/tacitus/tac.ann14.shtml 